\title{
Rettferdig tilgang til traumeforskning
}

\author{
«Kvart menneskes død minkar meg, \\ for eg høyrer menneska til.»
}

John Donne (1572-1631)

Dikteren John Donnes betraktninger fremstår som like aktuelle 400 år etter de ble nedtegnet (1). Årlig omkommer over fem millioner mennesker som følge av traumer, mens utallig flere påføres permanente eller midlertidige funksjonshemninger. Traumer utgjør et alvorlig, økende helseproblem som fører til store lidelser for individer, familier og samfunn. Den globale traumebyrden er størst i lavinntektsland hvor primærpreventive tiltak ofte er fraværende og helsevesenet er underdimensjonert til å møte utfordringene (2). Godt organiserte akuttmedisinske systemer og høykvalitets traumebehandling øker overlevelse (3), og mange av dødsfallene i lavinntektsland kunne ha vært unngått. Det finnes mange dyktige, hardt arbeidende kolleger som trosser de krevende arbeidsforholdene i lavinntektsland og tilbyr god traumebehandling. Selv om dedikert innsats i lokale prosjekter bedrer traumeomsorgen (4), er det påvist økt dødelighet etter ulykker i lavinntektsland sammenliknet med høyinntektsland (5). De sosioøkonomiske skadekonsekvensene forsterkes av at rehabiliteringstilbud og velferdsordninger er mindre utviklet.

\section{Truet tilgang til traumeforskning}

For å motvirke konsekvensene av manglende tilgang til akuttmedisinske ressurser må kostnadseffektive og feltvennlige tiltak identifiseres. Et eksempel på slik kunnskap fremgikk nylig i en randomisert kontrollert studie publisert i The Lancet. Studien hadde sjoner gjennom «Health InterNetwork for Access to Research Initiative», en avtale fremforhandlet av Verdens helseorganisasjon. Dessverre ser det nå ut til at flere av de større forlagene trekker seg fra denne avtalen (7). Det er bekymringsfullt at den vederlagsfrie tidsskrifttilgangen til våre kolleger nå er truet.

\section{Åpen tilgang til traumeforskning} Åpent tilgjengelige elektroniske fagtidsskrifter (open access) gir kostnadsfri brukertilgang til fagfellevurderte publikasjoner. Utgivelseskostnadene dekkes som regel gjennom en publiseringsavgift betalt av forfatteren. Artikkelforfatteren beholder opphavsretten til publikasjonen, men tillater leseren å laste ned og distribuere fullteksten vederlagsfritt. Tilgangen krever verken passord eller bibliotekarbistand og er en nettbasert brukervennlig kilde til oppdatert forskning. Antallet forlag som praktiserer slik publisering er økende og en rekke åpent tilgjengelige tidsskrifter har rukket å bli anerkjente innen sitt fagfelt $(8,9)$.

Norske myndigheter har uttrykt støtte til åpne publiseringskanaler (9) og har som målsetning at offentlig finansiert forskning skal være offentlig tilgjengelig (10). I Skandinavia viser Sverige vei, der all forskning finansiert av det statlige Vetenskapsrådet skal publiseres med åpen tilgang (11).

Det finnes flere internasjonale åpent tilgjengelige akuttmedisinske tidsskriftalternativer. Critical Care, Emergency Medicine Journal, Scandinavian Journal of Trauma, Resuscitation and Emergency Medicine og Archives of Orthopaedic and Trauma Surgery er eksempler på europeisk orienterte akuttmedisinske tidsskrifter med fri tilgang. Videre praktiserer Tidsskriftet åpen artik-

\section{«Fagutvilkling som utføres i høyinntekts- land bør av kollegial solidaritet gjøres globalt fritt tilgjengelig»}

som konklusjon at det forholdsvis rimelige medikamentet traneksamsyre reduserer dødelighet blant blødende traumepasienter (6). Helseinstitusjoner i lavinntektsland har begrenset mulighet til å betale dyre tidsskriftsabonnementer, selv om brukervennlig tilgang til forskning er en forutsetning for å kunne utøve oppdatert traumeomsorg. Til nå har man i lavinntektsland hatt åpen tilgang til mange vitenskapelige publika- keltilgang (12) og publiserer regelmessig artikler på engelsk. Parallelt tilbyr flere av de abonnementsbaserte tidsskriftene åpen tilgang til utvalgte artikler.

Forskere og klinikere med interesse for traumatologi har dermed tilstrekkelig anledning til å publisere åpent tilgjengelige artikler, og argumentene er åpenbare. Fagutvikling som utføres i høyinntektsland bør av kollegial solidaritet gjøres globalt fritt tilgjengelig. Åpen tilgang til oppdatert vitenskap kan bidra til en kvalitetsforbedring av traumeomsorgen som utjevner dødeligheten mellom fattig og rik.

\author{
Marius Rehn \\ marius.rehn@norskluftambulanse.no \\ Forskningsavdelingen \\ Stiftelsen Norsk Luftambulanse \\ Postboks 94 \\ 1441 Drøbak \\ og \\ Akershus universitetssykehus \\ Lørenskog

\section{Hans Morten Lossius} \\ Forskningsavdelingen \\ Stiftelsen Norsk Luftambulanse \\ og \\ Universitetet i Bergen
}

Oppgitte interessekonflikter: Ingen

Litteratur

1. Donne J. Eit menneske er inga øy. Dikt og prosa gjendikta av Åsmund Bjørnstad. Oslo: Aschehoug, 2010: 111-3.

2. Sasser S, Varghese M, Kellermann A et al. Prehospital trauma care systems. Genève: World Health Organization, 2005

3. MacKenzie EJ, Rivara FP, Jurkovich GJ et al. A national evaluation of the effect of traumacenter care on mortality. N Engl J Med 2006; 354: $366-78$.

4. Husum H, Gilbert M, Wisborg T et al. Rural prehospital trauma systems improve trauma outcome in low-income countries: a prospective study from North Iraq and Cambodia. J Trauma 2003; 54 : $1188-96$.

5. Mock CN, Jurkovich GJ, nii-Amon-Kotei D et al. Trauma mortality patterns in three nations at different economic levels: implications for global trauma system development. J Trauma 1998; 44: 804-12.

6. Shakur H, Roberts I, Bautista R et al. Effects of tranexamic acid on death, vascular occlusive events, and blood transfusion in trauma patients with significant haemorrhage (CRASH-2): a randomised, placebo-controlled trial. Lancet 2010; 376: 23-32

7. Koehlmoos T, Smith R. Big publishers cut access to journals in poor countries. Lancet 2011; 377: 273-6.

8. Lossius HM. Soreide K. Open access publishing: a girder in the success of the Scandinavian Journal of Trauma, Resuscitation and Emergency Medicine. Scand J Trauma Resusc Emerg Med 2011; 19: 7.

9. St.meld. nr. 20 (2004-2005). Vilje til forskning.

10. Forskningsrådets prinsipper for åpen tilgang til vitenskaplig publisering. Oslo: Norges forskningsråd, 2009

11. Vetenskapsrådet. Fri tillgänglighet till forskningsresultat - open access. www.vr.se/ omvetenskapsradet/strategierochriktlinjer/ fritillganglighetopenaccess (1.2.2011).

12. Jakobsson A, Nilsen R, Fossum S. Åpen tilgang og Tidsskriftets praksis. Tidsskr Nor Lægeforen 2007: 127: 1805.

Mottatt 3.2. 2011 og godkjent 17.2. 2011. Medisinsk redaktør Lars Frich 